\title{
Finding Archaeological Relevance during a Pandemic and What Comes After
}

\author{
Lynn H. Gamble $\mathbb{D}$, Cheryl Claassen, Jelmer W. Eerkens, Douglas J. Kennett, Patricia M. Lambert, \\ Matthew J. Liebmann, Natasha Lyons, Barbara J. Mills, Christopher B. Rodning, Tsim D. Schneider, \\ Stephen W. Silliman, Susan M. Alt, Douglas Bamforth, Kelley Hays-Gilpin, Anna Marie Prentiss, \\ and Torben C. Rick
}

\begin{abstract}
This article emerged as the human species collectively have been experiencing the worst global pandemic in a century. With a long view of the ecological, economic, social, and political factors that promote the emergence and spread of infectious disease, archaeologists are well positioned to examine the antecedents of the present crisis. In this article, we bring together a variety of perspectives on the issues surrounding the emergence, spread, and effects of disease in both the Americas and Afro-Eurasian contexts. Recognizing that human populations most severely impacted by COVID-19 are typically descendants of marginalized groups, we investigate pre-and postcontact disease vectors among Indigenous and Black communities in North America, outlining the systemic impacts of diseases and the conditions that exacerbate their spread. We look at how material culture both reflects and changes as a result of social transformations brought about by disease, the insights that paleopathology provides about the ancient human condition, and the impacts of ancient globalization on the spread of disease worldwide. By understanding the differential effects of past epidemics on diverse communities and contributing to more equitable sociopolitical agendas, archaeology can play a key role in helping to pursue a more just future.
\end{abstract}

Keywords: infectious diseases, COVID-19, epidemics and pandemics, inequality, Indigenous and Black communities, paleopathology, climate change, marginalization, material culture, history of disease

Este articulo surgió a medidas que atravesamos la peor pandemia mundial de un siglo. Con visión a largo plazo de factores ecológicos, económicos, sociales y políticos que promueven el aparecimiento y propagación de enfermedades infecciosas, los

Lynn H. Gamble (gamble@ anth.ucsb.edu, corresponding author) and Douglas J. Kennett $\square$ Department of Anthropology, University of California, Santa Barbara, CA 93106, USA

Cheryl Claassen a Department of Anthropology, Appalachian State University, Box 32016, Boone, NC 28608, USA

Jelmer W. Eerkens $\square$ Department of Anthropology, One Shields Ave, University of California, Davis, CA 95616, USA

Patricia M. Lambert — Department of Sociology, Social Work, and Anthropology, 0730 Old Main Hill, Utah State University, Logan, UT 84322-0730, USA

Matthew J. Liebmann $\square$ Department of Anthropology, Harvard University, 11 Divinity Avenue, Cambridge, MA 02138, USA Natasha Lyons - Ursus Heritage Consulting and Department of Archaeology, Simon Fraser University, 11500 Coldstream Creek Road, Coldstream, British Columbia, V1B 1E3, Canada

Barbara J. Mills $\square$ School of Anthropology, PO Box 210030, University of Arizona, Tucson, AZ 85721-0030, USA

Christopher B. Rodning $\square$ Department of Anthropology, Tulane University, 101 Dinwiddie Hall, 6823 Saint Charles Avenue, New Orleans, LA 70118, USA

Tsim D. Schneider Department of Anthropology, University of California, Santa Cruz, CA 95064, USA

Stephen W. Silliman $\mathbf{~ D e p a r t m e n t ~ o f ~ A n t h r o p o l o g y , ~ U n i v e r s i t y ~ o f ~ M a s s a c h u s e t t s , ~ B o s t o n , ~} 100$ Morrissey Boulevard, Boston, MA 02125-3393, USA

Susan M. Alt - Department of Anthropology, Indiana University, Bloomington, IN 47405, USA

Douglas Bamforth $\mathbf{~ D e p a r t m e n t ~ o f ~ A n t h r o p o l o g y , ~ U n i v e r s i t y ~ o f ~ C o l o r a d o , ~ B o u l d e r , ~ C O ~ 8 0 3 0 9 - 0 2 3 3 , ~ U S A ~}$

Kelley Hays-Gilpin $\square$ Department of Anthropology, Northern Arizona University, Flagstaff, AZ 86011-5200, USA

Anna Marie Prentiss a Department of Anthropology, University of Montana, Missoula, MT 59812, USA

Torben C. Rick Department of Anthropology, National Museum of Natural History, Smithsonian Institution, Washington, DC 20013-7012, USA

American Antiquity 86(1), 2021, pp. 2-22

Copyright (C) The Author(s), 2020. Published by Cambridge University Press on behalf of the

Society for American Archaeology. This is an Open Access article, distributed under the terms of the Creative Commons Attribution licence (http://creativecommons.org/licenses/by/4.0/), which permits unrestricted re-use, distribution, and reproduction in any medium, provided the original work is properly cited.

doi:10.1017/aaq.2020.94 
arqueólogos están en buena posición para examinar los antecedentes de la crisis actual. En este artículo, presentamos una variedad de perspectivas sobre cuestiones de aparecimiento, propagación, y efectos de enfermedades en las Américas y Afro-Eurasia. Reconociendo que las poblaciones humanas más afectadas por COVID-19 suelen ser compuestas de descendientes de grupos marginados, investigamos los vectores de enfermedades pre y post contacto entre las comunidades indígenas y negras en Norteamérica, describiendo los impactos sistemáticos de las enfermedades y las condiciones que agravan su propagación. Examinamos como la cultura material refleja y cambia como resultado de las transformaciones sociales provocadas por la enfermedad, los conocimientos que provee la paleopatología sobre la antigua condición humana, y los impactos de la antigua globalización en la propagación de enfermedades en todo el mundo. Al entender los efectos diferentes de epidemias pasadas en diversas comunidades y al contribuir a agendas sociopolíticas más equitativas, la arqueología puede tener un papel importante en formar un futuro más justo.

Palabras clave: enfermedades infecciosas, COVID-19, epidemias y pandemias, desigualdad, comunidades Indígenas y Negras, paleopatología, cambio climático, marginación, cultura material, historia de enfermedad

$\mathrm{I}$ deas for this article emerged as we experience the worst global pandemic in a century. It has affected all aspects of life-political, religious, economic - and social structures have been challenged at multiple levels. The primary goal of this article is to encourage scholars to consider the broader issues that the world confronts today and how we, as archaeologists, contribute to a greater understanding of similar issues that occurred in the past (Trigger 2006:546-548). Archaeologists are well positioned to examine the ecological, economic, social, and political factors that promote the emergence and spread of infectious disease over the long term. We hope to encourage scholars to use archaeological knowledge by applying it to broader topics of current significance in the world and to stimulate thinking on significant issues we face today-in this case, disease.

The ongoing COVID-19 global pandemic provides the most recent example of the economic devastation and human suffering caused by the rapid spread of infectious disease, exposing long-term weaknesses in infrastructure. Irrational behaviors-such as berating construction workers installing $5 \mathrm{G}$ networks because of the belief that they cause the virus, or suggestions by world leaders that the ingestion of bleach could be a cure for the disease-materialize as people cast blame, unable to believe or cope with scientific explanations. This pandemic illustrates how people do not always do the safest or most sensible things. Instead, long-term societal fractures are exposed and amplified. Events of the present provide an opportunity to tack backward and forward in time and use today's lessons to humanize archaeological analysis and contextualize the factors that drive human actions.

In this article, we begin with an examination of the historic period and the social issues surrounding the emergence, spread, and effects of disease. Inequality is a central concern in these discussions. Although inequalities are known to have developed within long-lived cultural traditions (Flannery and Marcus 2012; Kohler et al. 2017), they are most strongly associated with colonial situations. Human populations most severely impacted by COVID-19 are typically the descendants of those groups (Dávalos et al. 2020). We address epidemic (outbreaks affecting communities or regions vs. pandemics that are international in scale) disease among Indigenous groups in North America and Mexico, outlining systemic impacts of diseases and the conditions that can exacerbate their spread. The importance of mobility as a disease vector and as a strategy of avoidance and even resilience is also investigated. We then examine impacts of disease on Black communities as an effect of vulnerability and marginalization.

In the second part of the article, we address the interplay of material culture, palaeopathology, and demography. We investigate how material culture both reflects and changes as a result of social transformations brought about by disease. In addition, we examine new insights that paleopathology provides about the ancient human condition via traditional, recent, and emerging analytical techniques, with examples of diseases from the Americas both before and after European contact. The final section mirrors many of the issues in the COVID-19 pandemic. 
Here, we consider how the spread of infectious disease was particularly rampant among ancient societies, and how this spread was exacerbated by climate-induced crop failures that made populations more susceptible to disease. We conclude with thoughts about how the archaeological study of disasters, such as pandemics, can contribute to the growth of an archaeology that both furthers our understanding of the major challenges that humanity faces and supports the creation of equitable and scientifically supported agendas and solutions.

This article was written by the members of the American Antiquity Editorial Board during and in response to the COVID-19 pandemic. Through data, research, and analytical techniques, the texts that follow bring together different perspectives on the current situation and the way these relate to human actions of the past. The article provides a multivocal commentary that has the goal of providing insights that are useful in new research on human-disease interactions.

\section{Epidemic Disease among Indigenous Peoples, Black Communities, and Other Underrepresented Groups}

Best-selling books such as Jared Diamond's Pulitzer Prize-winning Guns, Germs, and Steel (1999) and Charles Mann's 1491 (2005) draw attention to the devastation of Indigenous communities due to epidemic diseases introduced through European colonialism. These works helped to popularize the notion that Indigenous depopulation was a natural outcome, due to particularities of geography and genes. Although biology and geography may have laid the foundations for what followed, this naturalization separates the actions of people from the spread of disease, shifting blame from European settler onto microbes and genetics.

Sustained archaeological research from across North America over the past 30 years demonstrates that the spread of epidemic diseases in the wake of European colonialism was complex (Hull 2009:220-282). Diseases did not spread independently from the actions of colonial agents, as hypothesized by a previous generation of scholars (e.g. Dobyns 1983). Advances in dating and spatial analytics show that epidemic diseases lagged behind initial contacts in many areas, rather than advancing in a wave ahead of European traders, settlers, and missionaries in the sixteenth century. In the U.S. Southwest, for example, the earliest evidence for postcontact Pueblo depopulation occurs nearly a century after first encounters with Europeans and Africans, and more than three decades after the establishment of the first colonial settlements in the region (Liebmann et al. 2016). Similarly, disease appears to have followed on the heels of colonial incursions in the U.S. Southeast, Northeast, Great Lakes region, and Far West, as well as on the Canadian Shield and the Northwest Coast (Jones 2014). In other areas, there is strong archaeological evidence of depopulation consistent with epidemic disease after initial contact but before sustained settlement (for example, progressive reduction in settlement and house sizes; Collison 2013; Kvamme and Ahler 2007).

The archaeology of colonial North America suggests that Indigenous depopulation due to infectious disease is not a matter of simple exposure to new germs, as evidenced by the lag between first encounters and Indigenous depopulation events. Nor are infectious diseases autonomous and wholly "natural" processes. Instead, as Dale Hutchinson (2016) suggests, infectious diseases are also social processes, the consequences of which are directly affected by human decisions and dispositions. Archaeology demonstrates that Indigenous peoples died in vast numbers after 1492 not only because Europeans introduced new diseases but because Europeans introduced social structures that promoted new forms of poverty, famine, malnutrition, violence, and dislocation. These haunts of colonialism, termed "structural violence" by medical anthropologist Paul Farmer (2004), worked in concert with disease to render Indigenous communities particularly vulnerable. Instead of causing injury through direct physical actions, structural violence refers to the economic, legal, political, and religious forces that place individuals and populations in harm's way.

Historical narratives inform how we think about Indigenous health and inequality today. The horrors of seventeenth-century "virgin soil" epidemics may appear to have been a unique occurrence — an accident of history (and 
biology) that could never occur again. But this position ignores the fact that Indigenous communities have suffered disproportionately negative health outcomes for more than 500 years. For Indigenous peoples living under colonial regimes, health disparities are a persistent fact of life. Whether we are talking about smallpox, measles, and typhus in the seventeenth and eighteenth centuries; tuberculosis in the nineteenth and twentieth centuries; or COVID-19 in the twenty-first. Today, Indigenous communities suffer deaths due to diabetes at more than three times and cardiovascular disease at twice the rate of the rest of the nation, and infant mortality rates double that of the rest of the U.S. population (Indian Health Service 2020). In the 1918 influenza pandemic, and again during the 2009 outbreak of swine flu (also known as H1N1), the death rate for Indigenous groups that contracted these diseases was four times that of all other racial and ethnic groups combined (National Library of Medicine 2020).

Tragically and unsurprisingly, Indigenous communities have been hit particularly hard by the novel coronavirus in 2020. In New Mexico, where Native Americans comprise $11 \%$ of the state's population, Indigenous persons accounted for 57\% of the state's 4,863 COVID-19 cases as of May 10, 2020 (New Mexico Department of Health 2020). The Pueblos of Zia and San Felipe reported some of the highest community infection rates in the country, at $3.4 \%$ and $2.36 \%$, respectively. Those rates exceeded that of New York City at the height of the spring 2020 pandemic (Chavez 2020). Once again, this is not a "natural" or inevitable situation. These statistics should cause us to reflect on how Indigenous peoples came to be more susceptible to COVID-19 than settler colonial populations. The novel coronavirus pandemic of 2020 shines new light on a terrible truth: the horrors of seventeenth- to nineteenth-century epidemics among Indigenous peoples were not a unique, one-time accident of history. It behooves us to think about how archaeologists can dismantle the enduring myths that continue to be used to rationalize health inequities in North America today as well as how we can contribute to processes, resources, and agendas that challenge this system. The way we think about the earliest days of European settlement in the Americas structures the way we think about Indigenous health disparities today.

\section{Mobility}

When we consider the impact of epidemic diseases, we also need to contemplate mobility, or the lack of it. In the spring and summer of 2020, local and national news focused on the growing malaise of citizens who were feeling not just increasingly frustrated about the uncertainty and tragedy of the COVID-19 pandemic but also bottled up at home. With the spreading influence of armed protesters seeking to "liberate" their home states from what they interpreted to be oppressive restrictions on their mobility and ability to work during a global pandemic_-along the way, grotesquely evoking the name and bravery of Rosa Parks to characterize their "plight" and resistance (Scott 2020)—some Californians assembled for protests at the capitol in Sacramento. Others hit the beach. Warm weather beckoned many outdoors in numbers, even if by doing so they not only defied the logic behind "flatten the curve," "social distancing," and "herd immunity," but also outright ignored state restrictions against gathering in public spaces. According to one analysis of cell-phone data (aggregated from an average of 18 million cell phones a day), differences emerged between those who dwell within densely populated metropolitan areas and "free-roaming" residents of many rural counties. A key social insight in this research is this: "State orders don't necessarily dictate behavior" (Schaul et al. 2020).

Mobility is at the core of human existence, and it is often infused with power and agency as seen in archaeological examples from colonial North America. Beginning in the fifteenth century when European colonists first set foot on Indigenous homelands, Native peoples experienced spiritual and physical harm, theft of land, threats to their cultures and identities, and deeply wounding impacts to their lives and livelihoods from invasive plant taxa, grazing livestock, and the spread of introduced diseases. Indigenous communities continue to negotiate the aftermath of these earlier phases of upheaval as well as the ongoing effects of sustained colonialism (Lightfoot and Gonzalez 2018). In the face of the 
severely reduced situations of Indigenous communities, it is understandable why anthropologists working to "salvage" unadulterated cultural knowledge from "vanishing" tribes in the early 1900s viewed missions and religious proselytizers as prime suspects in the story of loss visited far too often on Native peoples of North America. The adobe, stone, and thatched walls of missions came to define sturdy physical and intellectual barriers between modernity and a space where prehistory ends.

From mission "fortresses" described by borderland historian Herbert Bolton (1917:51) to the prison-missions narrated in the present (Madley 2019), popularized scholarly accounts of colonialism falsely depicted the immobility of Indigenous peoples even when living Indigenous peoples-and mounting archaeological evidence-suggest otherwise. Crossing ancestral lands and waters, Michelle Lelièvre and Maureen Marshall (2015) note, the mobility of Mi'kmaq people represented important political acts of sovereignty and emplacement that distressed Catholic missionaries operating in Nova Scotia. Mobilization to mesa-top refuges ensured access to spaces of protection and spiritual strength for Indigenous peoples throughout the Southwest following the 1680 Pueblo Revolt (e.g., Aguilar and Preucel 2019). Not to be caught flat-footed, Indigenous hunter-gather-fisher-managers of California frequently sequenced their visits to colonial missions-and their trips away from them-to coincide with seasonal harvests of food resources and to carry out mortuary rites, dances, and other social practices beyond the walls (Schneider 2015).

These and other examples from archaeology repeatedly show that mobility may be an act of agency in opposition to state control. Although symbolic of the power of the state to control and confine, walls do not necessarily dictate behavior. Stability of settlement in areas more remote from colonizing populations, particularly in the vast majority of the continent where no missions were ever established, underscores this. EuroAmerican settlement came late to the heart of North America and, even faced with diseasedriven depopulation, maize-farming communities on the Great Plains retained their traditional settlements, lifeways, and territories until late in the colonial era. These farmers built their own walls and resisted the changes around them from within (Bamforth 2021).

People's use of mobility as a political statement today is controversial but also acknowledged for just that - a conscious and empowering action against perceived state control. When considering archaeological examples of Indigenous mobility, why are we so slow to apply a lens of power and autonomy? In these instances, sovereignty and agency were even more central and consequential, and yet tropes of Indigenous loss and inaction endure. To be sure, these two contexts are different in their root causes and reasons for mobility. Recent efforts at mobility in the face of state-dictated restrictions, however, draw heavily on ideas of liberty and freedom from state oppressors. This sits in stark contrast to the archaeological interpretations of Indigenous mobility that largely downplay its significance, power dynamics, and sovereign political implications.

\section{Examples from Mexico}

We see many parallels among Indigenous peoples of Mexico, further demonstrating that disease does not stop at international borders. It is especially instructive to look at the subtler ramifications of the great death toll from numerous epidemics that hit central Mexico in the sixteenth century after contact between men from Europe with both women and men of Mexico living in urban settings. The resulting massive death toll brought about significant changes and begs the question of how many other times in human history similar changes - in regional settlement patterns, rituals, foodways, age profiles, economics, and political organization-have resulted from epidemics.

No fewer than four diseases - smallpox, measles, typhoid, and mumps-hit central Mexico within a 70 -year period, killing $90 \%$ of the population (Prem 1992). The first epidemic occurred in the middle of the first entrada (1520-1521), and the second one a decade later. Both epidemics exacted their highest toll among young Indigenous people. Some Spaniards died as well. This high death rate among Indigenous peoples of New Spain (central Mexico in particular) and low death rate among Spaniards 
led to a number of assertions about the differences between the Native's body and the Spaniard's body. Why was the Native body so fragile and the Spaniard so hardy? The Spaniards' explanation was that the climate of central Mexico and the Caribbean (stars overhead, latitude, humidity) feminized a man, as did the diet of the Indigenous peoples (root crops, insects, rodents, algae, and maize), which upset the humors. The European/Christian/civilized foods of wheat, wine/spirits, and mammalian meat made the ideal (masculine) body. The absence of these in New Spain eventually led to the rapid import of European foods, forever altering native foodways and causing environmental degradation from domesticated animals (Earle 2012) and land grabs for acreage within only a few decades.

Like COVID-19, the epidemics of the sixteenth century affected and stressed one segment of the population much more than it did others: it was members of the working class and the native population who died in astounding numbers (Earle 2012; Prem 1992). These deaths impacted not only rituals through the loss of practitioners and their esoteric knowledge, but also crafts through the loss of skilled craftspeople. The high quantity of deaths -19 million to 21 million in 70 years in New Spain-led to depopulation of Native settlements and, consequently, the loss of elements of landscape and place that underpinned ritual and identity. Spaniards and the Spanish language filled the vacant quarters. In some cases, the Native populations that survived remained in these places and repurposed churches while developing new understandings of ruins and their place in the cosmos.

Mobility was not an option for Catholic Natives, given that they were forced to work on missions, for government officials, or for Spaniards in mines and ranches; attend daily prayers and lessons; and report to their priest each weekend in larger towns. In writing about Natives in Jalisco, Gerónimo de Mendieta stated that "unlike other people in the world, they did not flee into the countryside when plague struck, instead staying together in their altepetl [towns] - only within the altepetl would they be assured a decent burial [Catholic procedure] and not die like animals [pagan ancestors]" (1971:519). Hospitals had been built in nearly every doctrina town by the 1580 s, so for the later epidemics, these hospitals - as well as the desire for a proper burial and access to provisions - attracted rural dwellers to the doctrina and visita towns, increasing the density of population.

Eventually depopulation changed the ability of Native peoples to pay tribute to their leaders, altering the quantities of goods, the variety of goods, and the geography and nodes of the tribute network. Similar to our current situation, these economic losses worked their way up the social hierarchy. The lack of goods from their subjects meant that the Native elite governors were unable to meet Spanish tribute (goods and labor) demands, costing them their favored place in the Spanish governmental hierarchy and the Native peoples their self-governance. Soon, the drastic decline in Indigenous labor available to work on ranchos and mines led to the rapid importation of new laborers-Africans, creating yet another culture contact situation.

\section{Inequality, Vulnerability, and Effects of Marginalization on African Americans}

Compared to the general U.S. population, the effects of COVID-19 have been much greater not only among Indigenous communities but also among Black groups. There are many reasons why. Historically and structurally, Black communities in the United States have had comparatively less access to health care, nutrition and fresh foods (given the "food deserts" in some urban areas), safe housing and neighborhoods that enable healthy lifestyles, and educational and employment opportunities that foster both flexibility and choice in career paths and living arrangements. These issues parallel those of Indigenous, Latinx, and Asian groups in the United States. The lives of people of color are more commonly affected by violent crime, aggressive and sometimes violent policing, and associated stresses and stressors. Many Black Americans and members of other marginalized groups hold jobs that cannot be done from home and/or performed while consistently maintaining social distancing. Many also have lost jobs because of the economic fallout of the coronavirus crisis, and-in part because of other factors noted here-they sometimes cannot find other jobs easily, thereby compounding other 
sources of vulnerability and susceptibility to disease and poverty.

This constellation of issues stems from the other multigenerational pandemic it represents: long-standing and virulent anti-Black racism and the extensive systemic and practical effects of white privilege and supremacy. Our duty as archaeologists is to make sure that those histories are not forgotten. They are precursors to the present, and these narratives and structural realities remind us that these conditions are not new nor are they "over." They have been present since Africans were first brought to the Americas (see New York Times 2019) enduring the horrors of the Middle Passage and perhaps never recovering entirely from the anguish and violence of those experiences. Despite being far from any place familiar or friendly, enslaved African persons then carved out lives in new settings, maintaining some aspects of traditional African cultural practices while adapting to American environments and landscapes of colonialism and imperialism. Archaeology sheds light on the resilience, resistance, strategy, and even opportunity pursued by African Americans in the plantation landscapes of the American South, the Chesapeake, and the Caribbean (e.g., Barnes and Steen 2012; Brown 2004; Ferguson 1992; McDavid 1997; Orser 1990, 1994; Samford 2007; Singleton 1985, 1995, 2010); in urban and rural settings in the American Northeast (e.g., Delle 2019; Matthews and McGovern 2015); and at sites associated with the Underground Railroad in the United States (e.g., Graff 2019; LaRoche 2014) and in Latin America (Balanzátegui 2018; Costa 2016; Weik 2004). Not surprisingly, bioarchaeological studies of the health of both enslaved and emancipated Africans and African Americans show notable bodily stresses from inadequate nutrition, poor dental health, lifelong manual labor, and infection (e.g., Blakey 2001; de la Cova 2011, 2014; Lambert 2006; Watkins 2012).

Emancipation of slaves in North America brought an end to the political imprimatur of enslavement and extraction of slave labor and lives, and archaeologists have been able to highlight the struggles and triumphs of Black Americans in the periods that followed, from Texas (Franklin and Lee 2019, 2020; Wilkie 2019) to
Massachusetts (Battle-Baptiste 2011; Lee 2019; Paynter and Battle-Baptiste 2019). However, violence and disenfranchisement of the rights of citizenship in the United States-and obstacles to African Americans having access to "life, liberty, and the pursuit of happiness"-persisted throughout the late 1800s and early 1900s (Barnes 2011; Botwick 2018). In ways that resonate with the current COVID-19 context, these disparities can be tracked in the realms of health and healthcare for Black populations and framed by gender and racial inequalities (e.g., Dunnavant 2017; Franklin and Wilson 2020). Similarly, legacies of racism have contributed to structural violence and persistence of poverty and oppression of African Americans in the United States since then (e.g., Fracchia 2019; Gray 2020). Clear examples highlighted by archaeologists include the perpetual cycles of violence inflicted on Black communities in the early twentieth century, such as the Tulsa Race Massacre in Oklahoma in 1921 (Odewale and Slocum 2020) and the Rosewood Massacre in Florida in 1923 (González-Tennant 2018).

Archaeology can reveal diverse forms of oppression and marginalization in past societies as well as ideologies that have promoted the interests of some groups while extracting labor and resources (and sometimes lives) from others. The archaeology of enslavement reveals patterns of architecture and settlement layout that materialized and naturalized power relations, and that enforced systems of discipline and surveillance, alongside evidence of many forms of resilience and resistance. The archaeology of African American life during the past 400 years illustrates important patterns and processes that shape race relations in the United States currently and that contribute to the heightened vulnerability of Black Americans to the present pandemic.

Archaeology can amplify this knowledge by raising up the voices of Black archaeologists and communities whose heritages are involved (e.g., Epperson 2004; Franklin 1997), following the \#BlackLivesMatter movement and its intersections with archaeology (see also Rosenzweig 2020). A virtual panel on June 26, 2020, "Archaeology in the Time of Black Lives Matter," drove home this point with six panelists (Justin Dunnavant, Ayana Flewellen, Maria 
Franklin, Alexandra Jones, Alicia Odewale, and Tsonie Wolde-Michael) and more than 1,600 online attendees. The current convergence of the twin pandemics of racism and COVID-19 demands that American archaeologists engage with this political moment. More than just researchers or even allies, archaeologists can serve as accomplices, shining light into the shadows previously cast by toppling monuments of colonizers and slavers.

\section{Epidemics, Pandemics, and Material Culture}

Archaeologists are well positioned to assess changes in material culture following widespread disease. Material culture figures prominently in present-day pandemic practices-such as the innovation and adoption of different mask styles, many of which are actively used to express membership in different social groups and shared ideologies. Perhaps even more than the hat styles in the classic article by Martin Wobst (1977), many masks convey emblematic styles (sensu Wiessner 1983) that explicitly reference political and ideological membership in social movements and other groups-such as Black Lives Matter (BLM) or Make America Great Again (MAGA) - as does even the choice of whether or not to wear a mask at all. The rapidity with which specific manufacturing technologies (folded, seamed, draped, or tubular), icons, and colors have been innovated and adopted in mask making and wearing provides an empirical record for looking at technological and semiotic networks. It also shows how styleboth emblematic and assertive-goes beyond representation to how our interaction with these objects creates and maintains new relationships, including membership in new social movements.

Ethnohistorically documented epidemics and pandemics also provide contexts for understanding their effects on material culture, such as the transmission of knowledge about how to make specific kinds of items, along with their distribution, uses, and consumption. Diseases can directly affect production by reducing the number of producers, creating population bottlenecks, and causing the loss of skilled knowledge bearers. For example, in 1876, a smallpox epidemic was introduced to Zuni by Mormon settlers of nearby Savoia (Ramah) that lasted until 1879. One observer estimated about a $50 \%$ loss in Zuni population (Baxter 1882). In their analysis of three consecutive museum collections made at Zuni by Smithsonian Institution anthropologists from 1879 to the mid-1880s, Margaret Hardin and Barbara Mills (2000) noted a strong pattern of change in vessel size and symmetry, with smaller bowls and more asymmetrical patterns predominating in the last collecting expedition of 1884-1885. They suggested that this was the result of the death of older, more skilled potters, who would have been the producers of larger vessels with more complex, symmetrical designs. Similarly, Sahnish (Arikara) pottery production shifted after smallpox epidemics of the late 1700 s to a thicker, less carefully decorated pottery that is attributed to population loss, increasing warfare, and greater labor demands on women (Krause and Hollenback 2016). In another Plains case, Pawnee potters stopped making cooking pots by the mid-1700s, at least in part because of economic decisions to put more labor in bison hide production (Beck 2020). In all three of these examples, pottery production did not disappear. In fact, pots remained important objects that persisted-even in the face of massive EuroAmerican incursions - and promoted identities of resilience in Indigenous groups (see also Hollenback 2012). Potters had agency, and their decisions on what to make themselves and what to acquire by trade were a means of ensuring cultural persistence.

Epidemics and pandemics can inspire religious innovations and changes in Indigenous practices to control diseases. For example, new religious movements have arisen out of "crises responses" to European-introduced diseases, such as the Chinigchinish religion in eighteenthcentury California (Preston 2002:76). In another example, John Creese (2017) cites the increased use of a particular style of effigy-smoking pipes by the Wendat following epidemics of European diseases during the 1630s and 1640s. These objects were used in rituals of healing that involved smoking, an activity that by definition involves breath in all its layered meanings. Changes in mortuary ritual have also been connected with seventeenth-century epidemics in 
southern New England, where Native Americans buried their kin with European cloth to create a "protective" layer to the body (Bragdon 2017:122). Such changes are not simply acculturative acts. They are the selective use of new kinds of objects by Indigenous groups because of those objects' perceived abilities to affect what were dramatic transformations in their respective worlds.

Research worldwide demonstrates that material culture consumption may be used as an independent proxy for assessing the impact of pandemics on population loss, but with caveats. In eastern England, archaeological contexts dating before and after the Black Death showed a $45 \%$ decrease in the amount of pottery deposited (Lewis 2016). By contrast, Lee Mordechai and colleagues (2019) use material culture to argue against "maximalist" interpretations of mortality figures (cf. Meier 2016) during the Justinianic Plague of AD 541-544 in the Mediterranean region. Drawing on multiple datasets, they showed that the expected drop in frequencies of coins, inscriptions, papyri, and other well-dated materials did not occur during or after the pandemic. Their conclusions are supported by well-resolved palynological records showing no evidence for "rewilding," or decreases in agricultural production, as they did following the Black Death. The use of multiple environmental and material culture datasets to challenge narratives of disease has also been employed in North America to demonstrate the resistance and resilience of Indigenous populations rather than their disappearance (Holland-Lulewicz et al. 2020).

\section{Paleopathology and Insights into Ancient Human Disease}

Paleopathology can provide crucial insights into the history of human health and disease (Buikstra 2010). Much of this research has focused on chronic diseases such as degenerative joint disease, malnutrition, and dental caries - conditions that leave macroscopic markers on bones and teeth. By comparison, development of knowledge about the history of most infectious diseases has been slower. Historical texts, cases of preserved pathological soft tissue (e.g., mummies), and macroscopic parasites recovered from archaeological context have provided some key insights (Camacho and Reinhard 2020; Nerlich et al. 2006; Reid et al. 1999), but unfortunately, such materials are rare, or they are not systematically sought from the archaeological record.

Advances in biomolecular analytical techniques have opened new windows into the study of ancient disease, especially those of infectious origin (Nerlich 2018). Many of these techniques were developed within medical, forensic, and other STEM sciences, but they require unique modifications when applied to ancient materials. Together, they provide archaeology with new and independent datasets to test hypotheses about the long-term evolution of human disease and human-pathogen interactions.

Within this developing field, two main approaches are emerging. The first, and probably most direct, is the detection of pathogens themselves, typically by way of the unique biomolecular signatures they leave behind. Paleogenomics, or the study of genetic material from ancient pathogens, has been the most fruitful of these approaches. Ancient DNA (aDNA) unique to pathogens associated with tuberculosis (Mycobacterium tuberculosis; Salo et al. 1994), syphilis (Treponema pallidum; Schuenemann et al. 2018), Chagas disease (Trypanosoma cruzi; Aufderheide et al. 2004), and meningococcal disease (Neisseria meningitidis; Eerkens et al. 2018), among others, has been recovered from archaeological human and animal remains in the Americas. Although bones and teeth are most commonly studied, the recent recognition that aDNA and other biomolecules are well-preserved in dental calculus has opened large areas of the world to this type of analysis (Warinner, Rodrigues, et al. 2014).

At the same time, there is still a sizable gap between the screening of archaeological materials for aDNA of pathogenic microbiota and the ultimate goal of making inferences about ancient epidemics and pandemics from such data. The fragile nature of the double-helix DNA molecule makes recovery of aDNA challenging (Pääbo et al. 2004; Willerslev and Cooper 2005), and ancient RNA-based viruses even more so (Smith and Gilbert 2019). Because aDNA fragments must be compared to reference databaseswhich, in most cases, only include known modern 
pathogens-we are potentially overlooking a wide range of unknown and more ancient pathogens and diseases. That said, there are some recent successes, such as the extraction of ancient influenza from preserved human tissues dating to the early 1900s (Kobasa et al. 2004). Beyond aDNA recovery, many microorganisms are opportunistic pathogens within the human body, causing no disease in the face of an active immune system but turning pathogenic in a weakened state (e.g., tubercular bacilli). As is evident in the case of COVID-19, humans can be asymptomatic carriers of a pathogen, so simply detecting the aDNA or RNA of a pathogen does not indicate ancient disease, at least for the individual from whom it was obtained.

Paleoproteomics is a second emerging biomolecular approach, although it is not as developed as paleogenomics. Once again, dental calculus is proving to be a rich source for a wide range of ancient proteins (e.g., Hendy et al. 2018; Warinner, Hendy, et al. 2014). Proteins have several advantages relative to aDNA in paleopathology research. First, they are inherently more stable than DNA - especially those that bind to mineral surfaces in bone, dental tissues, or calculuswhich makes their preservation in ancient samples more likely. Tammy Buonasera and colleagues (2020) recently showed that amelogenin protein signatures in human teeth show negligible degradation over a 2,000-year window, whereas aDNA from the same set of individuals shows an order-of-magnitude decrease in signal. Second, proteins are produced by both pathogen (antigen) and host (antibody), potentially providing greater insight into the interaction between the two. For example, antigen proteins associated with sarcoma cancer have been identified in archaeological bone (Bona et al. 2014), whereas Jessica Hendy and colleagues (2016) recovered a wide range of human antibody proteins from mummified lung tissue samples. Although they can show an immune response to an infection, compared to DNA, proteins are often less indicative of a particular disease.

Reconstructing ancient outbreaks and epidemics from the archaeological record using paleogenomic and paleoproteomic approaches is still quite difficult, especially in the absence of written records. Of course, there are a number of ethical and logistical issues to address with descendant communities prior to commencing such studies, particularly when analyses are partially destructive (Bardill et al. 2018; Fox 2020). These issues aside, methodologically, one of the major challenges is working with partial or incomplete data-not only in terms of biomolecular preservation and incomplete knowledge about possible diseases but also in terms of archaeological sampling. Most paleopathology successes are at the scale of a single or small number of individuals, and they employ multipronged analytical strategies. Using multiple sources of partial data, such as fragments of aDNA, degraded proteins, nonspecific lesions on bone, and skeletal elements that happen to survive, we are able to make strong cases for particular diagnoses. By contrast, documenting ancient outbreaks and epidemics requires verification of synchronous infection across many individuals and/or sites. Another key concern here is knowing the rate of false positives and false negatives, similar to the osteological paradox that challenges interpretations of osteological data (Wood et al. 1992). This is especially difficult, for example, when a diagnosis is based on osteological lesions in one skeleton, and aDNA in the dental calculus of another, whereas a third individual has neither osteological lesions nor calculus. Without estimates for false positive —and especially for false negative - it is difficult to estimate the rate at which a disease affected members of a population.

Rather than attempting to mimic modern epidemiology's focus on tracking epidemics by learning a little bit (disease vs. no disease) about a lot of contemporaneous people, the real strength of our discipline lies in learning a lot about a select few individuals and then extending those results to the long timescales we are privy to. In this respect, documenting the origins of diseases as well as providing a rich socialmaterial context for their subsequent development and geographic spread over centuries or millennia are areas where archaeology can make significant contributions, whereas establishing morbidity rates within populations or $\mathrm{R}_{0}$ for ancient pathogens is not currently feasible. 
Infectious Disease in the Americas before and after European Contact

As bioarchaeologists have long noted, the Americas were not a disease-free environment before the arrival of Europeans (Larsen 1994; Martin and Goodman 2002; Merbs 1992), and, as elsewhere in the world, infectious disease likely shaped the biocultural landscape of the Americas in ways that have yet to be fully understood. From the beginning, ancient Americans would have carried microorganisms such as $H$. pylori and other potentially pathogenic bacteria (e.g., streptococci and staphylococci) and fungi (e.g., Candida albicans) with them across the Bering Land Bridge or other routes of entry (Araújo et al. 2013; Darling and Donoghue 2014; Merbs 1992). Microbes such as these are common components of human microbiomes (e.g., oral, gut, skin), communities of microorganisms that play a crucial role in human health and disease (Lloyd-Price et al. 2016). Although we know strikingly little at present about the microbiota of ancient Americans, there is great potential for their elucidation through the study of aDNA in human coprolites and tooth calculus (e.g.,Warinner et al. 2015). Host-specific parasites such as hookworm, pinworm, and whipworm would also have traveled with humans to the Americas, although the timing of their arrival and routes of travel have yet to be clarified (Araújo et al. 2013). Early migrants may also have introduced anthrax to the Americas, transporting the bacteria on animal hides as early as $13,000 \mathrm{BP}$ and possibly contributing to Pleistocene extinctions-although, again, more work is needed to evaluate prehistoric human impacts on pathogen-host ecology in North America (Nickell and Moran 2017).

Once in the Americas, human populations would have been exposed to a range of new pathogens through their interactions with American flora and fauna (Darling and Donoghue 2014), including Lyme disease (Borrelia burgdorferi; Margos et al. 2008), Carrion's disease (Bartonella bacilliformis; Allison et al. 1974), salmonellosis (Salmonella sp.; Sawicki et al. 1976), and tularemia (Francisella tularensis; Farlow et al. 2005). Protozoan diseases such as giardiasis (Giardia sp.; Nickell and Moran
2017), leishmaniasis (Leishmania sp.; Costa et al. 2009), toxoplasmosis (Toxoplasma gondii; Lehmann et al. 2006), and Chagas disease (Tripanosoma cruzi; Aufderheide et al. 2004) were also present in some environments. Other endemic pathogens, such as the spores of Coccidioides immitis and Blastomyces dermatitidis (Merbs 1992; Ortner and Putschar 1981), may have lain dormant in the ground until people began to disturb contaminated soils with the transition to agriculture. Many of these diseases would have been localized to areas where pathogens and insect vectors lived, although longdistance trade could have exposed traders from distant locales to "new" pathogens as they passed through affected areas (Merbs 1992). It is likely that other pathogens, such as the widely distributed hantaviruses, would have periodically affected individuals and households through infestations by reservoir species (rodents), as occurred in 1993 in the Four Corners region (Jonsson et al. 2010)—inexplicable events that could well have stimulated cultural responses such as the burning of affected houses and accusations of witchcraft.

Domestic animals, a common source of disease in Afro-Eurasian contexts (Wolfe et al. 2007), were rare in the Americas, and they do not appear to have served as major reservoirs for pathogens affecting humans there. That said, turkeys and macaws may have exposed people in the American Southwest and Mesoamerica to avian-borne diseases such as psittacosis (Chlamydia psittaci; e.g., Dickx and Vanrompay 2011), and their feces (cf. Lipe et al. 2016) could have contaminated water or food supplies with pathogenic bacteria. Human feces would also have created health risks (e.g., E. coli and Salmonella infections) when people began to settle into permanent villages, leading to diarrheal disease and possibly spreading other infections as a result of poor sanitation (as still occurs in many world regions today).

Diseases transmitted directly or indirectly from human to human (e.g., hepatitis B, see Roman et al. 2014; Herpes simplex, see Wertheim et al. 2014) were also present in precontact North American populations (Merbs 1992; Nickell and Moran 2017), although their 
presence has often been difficult to establish archaeologically because few affect the bones. Treponematosis (Treponema pallidum subsp.?) and tuberculosis (Mycobacterium tuberculosis) are two infectious diseases that do have distinct osteological signatures and widespread distribution, and both are well documented in the Americas before contact (Baker et al. 2020; Harper et al. 2011; Powell and Cook 2005; Roberts and Buikstra 2003). These are chronic bacterial infections that could be maintained in smaller populations through carriers and affected individuals (Ortner and Putschar 1981; Powell and Cook 2005), emerging as major (or at least more visible) diseases when people began to settle into permanent villages with the transition to agriculture (Larsen 1994; Powell and Cook 2005; Roberts and Buikstra 2003). Treponematosis affected Indigenous Americans for thousands of years before European contact (Baker et al. 2020; Powell and Cook 2005), whereas tuberculosis may have been introduced only a couple of millennia before the arrival of Europeans, perhaps through infected sea mammals hunted on the west coast of South America (Bos et al. 2014). The study of these chronic infections has recently been energized by advances in aDNA research (e.g., Bos et al. 2014; Schuenemann et al. 2018), and the potential for further elucidation of the origins and phylogenetic history of these and other infectious diseases through such studies is enormous-if researchers involved in the study of human skeletal remains collaborate with and seek permissions from descendant communities to obtain tissue samples from affected individuals. There is also much still to be learned about environmental influences on the skeletal manifestations of these chronic infections through careful analysis of lesion characteristics and distribution in the body (cf. Baker et al. 2020; Lambert 2017).

With the arrival of Europeans and enslaved Africans came the collective Afro-Eurasian disease load (e.g., chickenpox, cholera, diphtheria, influenza, malaria, measles, mumps, plague, smallpox, typhoid, and yellow fever; Bryant et al. 2007; Larsen 1994; Wolfe et al. 2007), including diseases that had made the jump from domestic animals or wild nonhuman primates, as well as those with a long history of human- to-human transmission (Wolfe et al. 1998, 2007). New and more virulent strains of treponemal disease (venereal syphilis; Baker et al. 2020) and tuberculosis also appear to have arrived with Europeans, the latter likely swamping out ancient American strains of tuberculosis in a complex exchange of genetic material that is only beginning to be understood (Bos et al. 2014; Pepperell et al. 2011; see also Kay et al. 2015).

One often overlooked (but see Merbs 1992) aspect of European contact that warrants further consideration is the arrival of Norse explorers on the east coast of Canada around AD 1000, long before Columbus. Their settlement at L'Anse aux Meadows in Newfoundland was populated by some 70-90 people (mostly male), and it served as a hub for coastal exploration and resource acquisition for the Greenland colony for several years at least. According to Icelandic sagas, summer and fall collecting of timber and grapes took place to the south, likely in New Brunswick, where the Norse foraged in the same coastal estuary as large groups of aboriginal people (Wallace 2003). It is not inconceivable that disease exchange occurred in contexts such as this that brought Norse explorers into close contact with Indigenous Americans. Consider, for example, emerging evidence that strains of smallpox were circulating widely in populations of northern Europe during the Viking Age (Mühlemann et al. 2020).

Ecology of Infectious Disease, Agriculture, and Demographic Transitions

Major concerns exist today regarding the emergence and spread of infectious diseases associated with the expansion of global food production necessary to feed a projected 11 billion people by 2100 (Rohr et al. 2019). The archaeology of complex systems provides a framework (sensu Kohler 2012) for considering the causes and consequences of such interactive processes in the spread of infectious disease. The ongoing COVID-19 pandemic demonstrates how the exogenous destabilizing effects of a rapidly spreading infectious disease can impact economic well-being, and it must be studied as interacting processes occurring on different spatiotemporal scales (Ceddia et al. 2013). 
Plant and animal domestication during the last 10,000 years has been one of the most consequential cultural and environmental transitions in the history of our species (Smith and Zeder 2013), and it has fundamentally changed the ecological and population dynamics involved with the transmission and spread of infectious diseases. The spread of agricultural and pastoral societies throughout Eurasia, Africa, and the Americas (e.g., Bellwood 2005; Bramanti et al. 2009; Skoglund et al. 2013) put humans in closer contact with other animal species carrying a variety of zoonotic diseases-just as what occurred with bats in China, which are thought to be the primary source of COVID-19. Pastoral populations spreading through Eurasia and Africa were in close association with domesticated animals that were the primary vectors for a range of diseases (e.g., measles from cattle, influenza from pigs and ducks [Diamond 2002]). Modeling approaches have demonstrated that even small populations consistent with early farming communities were large enough to sustain the circulation of some viruses, such as Brucella melitensis in goat populations in the Near East (Fournié et al. 2017). Infectious diseases resulting from the transition to agriculture and pastoralism in Eurasia ultimately devastated Indigenous populations in the Pacific Islands, Australia, and the Americas as Eurasian explorers and colonists came into contact with populations lacking immunity. High mortality rates in the Americas caused by introduced diseases contributed to the loss of traditional knowledge and lifeways as Europeans expanded across the continents.

A major demographic shift accompanied the transition from foraging to farming that had significant implications for the spread of infectious diseases (Bocquet-Appel 2011). Increases in population are thought to be related to decreases in mobility and reductions in birth interval. Population aggregation and urbanization in the last 5,000 years has led to supply chain issues required to feed growing populations (Zeder 1991) and resulted in the contamination of drinking water due to animal and human waste. Larger populations are also required to sustain many infectious diseases (e.g., 300,000 people for measles [Armelagos and Harper 2005]), and long-distance trade and interaction would have served to disperse infectious diseases more broadly. Wealth and health disparities also became much more visible in early urbanized societies. Overall, the Neolithic demographic transition was associated with increases in both morbidity and mortality. Traditional bioarchaeological indicators of disease fail to capture evidence for large-scale epidemics of acute infections because people either recovered with immunity or were killed quickly without osteological evidence (Ramenofsky 2003). As noted above, however, a variety of biomolecular approaches are now providing a new lens to examine infectious disease and revolutionize our ability to examine the dynamics of infectious disease in the past (e.g., Mühlemann et al. 2020; Schuenemann et al. 2018).

The plague, or "Black Death," touched upon earlier, provides one well-studied archaeological example of the ecological, economic, social, and political dynamics involved with the emergence and spread of a highly virulent infectious disease. The disease ravaged Europe between approximately AD 1347 and 1351, killing $30 \%-60 \%$ of the population and devastating economic, social, and political systems (DeWitte 2016). Skeletal assemblages in mass burial grounds combined with historical accounts provide a stark account of what unfolded as the disease spread rapidly through the population. As would be expected, the disease killed people too quickly to leave osteological evidence, but ancient DNA consistent with a virulent strain of bubonic plague bacterium (Yersinia pestis) has been extracted from teeth in Europe and Asia (Rasmussen et al. 2015). The age and sex composition of these mass burial grounds has been studied in detail, and it demonstrates that the disease selectively killed the elderly and individuals who had experienced physiological stress prior to the epidemic (DeWitte and Wood 2008). Strontium and oxygen isotopic data from a mass burial in London demonstrated that roughly $15 \%$ of the burial population were immigrants from the countryside, suggesting that mobility contributed to the spread of the disease (Kendall et al. 2013). The Black Death epidemic also occurred in the wake of a climate-driven famine throughout Europe that reduced health and 
increased frailty in the population, intensifying susceptibility to the disease (DeWitte 2015).

The transmission of infectious diseases is known to be exacerbated by climate change, and economic well-being is diminished by crop failures, making individuals more susceptible to negative health outcomes (Patz et al. 2005). Climate-driven famine and increasing human frailty just prior to the Black Death epidemic is consistent with this idea. There are other historical instances where climate change, famine, and disease outbreaks also co-occur. Archaeological and historical data for epidemics in the Ming and Qing Dynasties (1369-1901) indicate that epidemics flared up in the context of climate change that depressed economic well-being throughout China (Speir et al. 2016). Episodic drought in the Maya lowlands has also been linked to crop failure and severe famine that resulted in disease outbreaks and increases in mortality and migration (Hoggarth et al. 2017). Consequently, the archaeological record provides long-term datasets useful for assessing the dire nature of increasing health risks that could be associated with future climate predictions.

\section{Conclusion}

Felix Riede (2017) emphasizes that by understanding the impacts of catastrophes and disasters in the past, we can also focus on ideas about resilience within narratives of "pastforwarding" that make archaeology relevant to the present. Although he was speaking largely of environmental catastrophes, the same goal underlies our project here. We might ask, "Are disruptions from epidemics and pandemics different from other disasters, especially natural disasters such as volcanic eruptions, earthquakes, or hurricanes?" Pandemics are different from these environmental disasters in at least one major way: pandemics have a different temporality and geographic scale. As our contemporary situation shows, contagious diseases have much longer periods in which they affect populations, and they may even come in waves that endure over months, if not years-although some disasters, such as volcanic eruptions, may be sporadic over long periods of time as well. There are, however, many commonalities-population loss and displacement, disruptions in production and supply chains, transformations in social networks, institutional breakdowns, decreases in human and community security, and many other aspects of lived human experience that change in the wake of disasters (e.g., Hegmon and Peeples 2018). On a more aspirational note, Michelle Hegmon and Matthew Peeples (2018) observe that the negative impacts of social transformation are mitigated by a strong sense of community security, which should spur us as individuals and collectives to better create these moving forward. The exclusion of pandemics from much of the archaeological literature on disasters drives our comments here, and we hope that they contribute to our own resiliency.

As archaeologists explore the relevance of the human past to understanding a variety of contemporary societal issues-including climate change, the biodiversity crisis, and broader societal inequities (Kintigh et al. 2014)—infectious disease, epidemics, and pandemics are another important area of inquiry. The archaeological and historical records from the Americas demonstrate the abundance of past epidemics-especially during the colonial era-and the often transformative societal inequities that emerged from these epidemics, as well as their effects on material culture. These examples illustrate the interconnections between the events of several centuries ago and the continued injustices of today, particularly in Indigenous communities, Black communities, and other diverse communities.

Researchers are well equipped with tools and models to help understand past disease (e.g., aDNA, proteomics, complex systems modeling), but significant obstacles to determining if past disease resulted in epidemics or even pandemics remain. Given the long history of epidemics and pandemics, the COVID-19 pandemic will not be the last, which makes research on disease, disease prevention, and societal responses to outbreaks a high priority. Archaeology has a key role to play in the future study of disease, especially by highlighting the differential effects of past epidemics on Indigenous and other diverse communities as well as helping pursue a more equitable and just future. 
Acknowledgments. This truly was a collaborative effort, and every American Antiquity Board member made significant contributions. Lynn Gamble is listed first because she conceived of the idea for the article and contributed sections throughout, primarily to the introduction and conclusion, as well as transitions between sections. She also guided the authors through the entire process. Authors with primary roles - those who contributed substantial sections-are next listed in alphabetical order. These are followed by those who wrote short sections or primarily provided editorial changes and comments. They are also listed in alphabetical order. Jelmer Eerkens wrote the introductory section on paleopathology and insights into ancient human disease. Pat Lambert contributed the section on infectious disease in the Americas before and after European contact. This is followed by a section that Doug Kennett wrote on the ecology of infectious disease, agriculture, and demographic transitions. $\mathrm{He}$ also contributed to the introductory material, with some additions by Natasha Lyons and Torrey Rick. Torrey Rick also helped edit the entire document and wrote the concluding paragraph. In addition to authoring the abstract and short sections throughout, Natasha Lyons thoroughly edited and commented on the article, and she provided help with references and many other aspects. Barbara Mills wrote the section on epidemics, pandemics, and material culture, and she was key in supporting the original ideas of the article. Matt Liebmann authored the introductory material in the section on epidemic disease among Indigenous peoples, Black Americans, and other underrepresented groups. Tsim Schneider, who wrote the section on mobility, was also involved throughout the process. Cheryl Claassen provided the section on examples from Mexico. Steve Silliman and Chris Rodning wrote the section on inequality, vulnerability, and effects of marginalization on Black Americans. Doug Bamforth wrote some brief sections throughout and contributed ideas, as did Susan Alt, Kelley Hays-Gilpin, and Anna Prentiss. The participation of the entire board in this unusual collaboration contributed to the diverse perspectives and depth of knowledge. We also acknowledge Tim Kohler, who served as guest editor for the article and provided constructive comments, as well as two peer reviewers who helped improve it. In addition, Glenn Russell reviewed different iterations of the article, and Alicia Gorman oversaw the early editorial process. Finally, we thank Jessica Morales, who translated the abstract into Spanish.

Data Availability Statement. No primary data were used for this article.

\section{References Cited}

Aguilar, Joseph, and Robert W. Preucel

2019 Seeking Strength and Protection: Tewa Mobility during the Pueblo Revolt Period. In The Continuous Path: Pueblo Movement and the Archaeology of Becoming, edited by Samuel Duwe and Robert W. Preucel, pp. 149-165. University of Arizona Press, Tucson.

Allison, Marvin J., Alejandro Pezzia, Enrique Gerszten, and Daniel Mendoza
1974 A Case of Carrións Disease Associated with Human Sacrifice from the Huari Culture of Southern Peru. American Journal of Physical Anthropology 41:295300.

Araújo, Adauto, Karl Reinhart, Luiz Fernando Ferreira, Elisa Pucu, and Pedro Paulo Chieffi

2013 Paleoparasitology: The Origin of Human Parasites. Arq Neuropsiquiatr 1(9-B):722-726.

Armelagos, George J., and Kristin N. Harper

2005 Genomics at the Origins of Agriculture, Part One. Evolutionary Anthropology: Issues, News, and Reviews 14:68-77. DOI:10.1002/evan.20047.

Aufderheide, Arthur C., Wilmar Salo, Michael Madden, John Streitz, Jane Buikstra, Felipe Guhl, Bernardo Arriaza, Colleen Renier, Lorentz E. Wittmers Jr., Gino Fornaciari, and Marvin Allison

2004 9,000-Year Record of Chagas' Disease. Proceedings of the National Academy of Sciences of the United States of America 101:2034-2039.

Baker, Brenda J., Gilliam Crane-Kramer, Michael W. Dee, Lesley A. Gregoricka, Maciej Hennenberg, Christine Lee, Sheila A. Lukehart, David C. Mabey, Charlotte A. Roberts, Ann L. W. Stodder, Anne C. Stone, and Stevie Winingear

2020 Advancing the Understanding of Treponemal Disease in the Past and Present. Yearbook of Physical Anthropology 171(Suppl. 70):5-41.

Bamforth, Douglas B.

2021 An Archaeological History of the Great Plains. Cambridge University Press, Cambridge, in press.

Bardill, Jessica, Alyssa C. Bader, Garrison Nanibaa'A, Deborah A. Bolnick, Jennifer A. Raff, Alexa Walker, and Ripan S. Malhi

2018 Advancing the Ethics of Paleogenomics. Science 360:384-385.

Barnes, Jodi A. (editor)

2011 The Materiality of Freedom: Archaeologies of PostEmancipation Life. University of South Carolina Press, Columbia.

Barnes, Jodi A., and Carl R. Steen

2012 Archaeology and Heritage of the Gullah People. Journal of African Diaspora Archaeology and Heritage $1: 167-224$

Battle-Baptiste, Whitney

2011 Black Feminist Archaeology. Routledge, London.

Baxter, Sylvester

1882 The Father of the Pueblos. Harper's New Monthly Magazine 65(385):72-91.

Beck, Margaret

2020 Pawnee Vessel Function and Ceramic Persistence: Reconstructed Vessels from the Burkett, Barcal, Linwood, Bellwood, and Horse Creek Sites. Plains Anthropologist 65:203-226. DOI:10.1080/00320447.2019. 1707852.

Bellwood, Peter S.

2005 First Farmers: The Origins of Agricultural Societies. Blackwell, Malden, Massachusetts.

Blakey, Michael

2001 Bioarchaeology of the African Diaspora in the Americas: Its Origins and Scope. Annual Review of Anthropology 30:387-442.

Bocquet-Appel, Jean-Pierre

2011 When the World's Population Took Off: The Springboard of the Neolithic Demographic Transition. Science 333:560-561. DOI:10.1126/science.1208880. 
Bolton, Herbert E.

1917 The Mission as a Frontier Institution in the Spanish American Colonies. American Historical Review 23:4261.

Bona, Agnes, Zoltan Papai, Gabor Maasz, Gabor A. Toth, Eva Jambor, Janos Schmidt, Csaba Toth, Csilla Farkas, and Laszlo Mark

2014 Mass Spectrometric Identification of Ancient Proteins as Potential Molecular Biomarkers for a 2000Year-Old Osteogenic Sarcoma. PLoS ONE 9(1): e87215. DOI:10.1371/journal.pone.0087215.

Bos, Kirsten I., Kelly M. Harkins, Alexander Herbig, Mireia Coscolla, Nico Weber, Iñaki Comas, Stephen A. Forrest, Josephine M. Bryant, Simon R. Harris, Verena J. Schuenemann, Tessa J. Campbell, Kerrtu Majander, Alicia K. Wilbur, Ricardo A. Guichon, Dawnie L. Wolfe Steadman, Della Collins Cook, Stefan Niemann, Marcel A. Behr, Martin Zumarraga, Ricardo Bastida, Daniel Huson, Kay Nieselt, Douglas Young, Julian Parkhill, Jane E. Buikstra, Sebastien Gagneux, Anne C. Stone, and Johannes Krause

2014 Pre-Columbian Mycobacterial Genomes Reveal Seals as a Source of New World Human Tuberculosis. Nature 514:494-497.

Botwick, Bradford

2018 Gullah-Geechee Settlement Patterns from Slavery to Freedom: Investigation of a Georgia Plantation Slave Quarter. North American Archaeologist 39:198-228.

Bragdon, Kathleen J.

2017 Our Strange Garments: Cloth and Clothing among Native Elites in 17th-Century New England. In Foreign Objects: Rethinking Indigenous Consumption in American Archaeology, edited by Craig N. Cipolla, pp. 110-126. University of Arizona Press, Tucson.

Bramanti, Barbara, Mark G. Thomas, Wolfgang Haak, Martina Unterlaender, Pia Jores, Kristiina Tambets, Indre Antanaitis-Jacobs, Miriam N. Haidle, Rimantas Jankauskas, Claus-Joachim Kind, Friedrich Lüth, Thomas Terberger, Jan Hiller, Shuichi Matsumura, Peter Forster, and Joachim Burger

2009 Genetic Discontinuity Between Local Hunter-gatherers and Central Europe's First Farmers. Science 326 (5949):137-140. DOI:10.1126/science.1176869.

Brown, Kenneth L.

2004 Ethnographic Analogy, Archaeology, and the African Diaspora: Perspectives from a Tenant Community. Historical Archaeology 38(1):79-89.

Bryant, Juliet E., Edward C. Holmes, and Alan D. T. Barrett 2007 Out of Africa: A Molecular Perspective on the Introduction of Yellow Fever Virus into the Americas. PLoS Pathogens 3(5):0668-0673.

Buikstra, Jane E.

2010 Paleopathology: A Contemporary Perspective. In A Companion to Biological Anthropology, edited by Clark S. Larsen, pp. 395-411. Wiley-Blackwell, Chichester, United Kingdom.

Buonasera, Tammy, Jelmer Eerkens, Alida de Flamingh, Laurel Engbring, Julia Yip, Hongjie Li, Randall Haas, Diane DiGiuseppe, Dave Grant, Michelle Salemi, Charlene Nijmeh, Monica Arellano, Alan Leventhal, Brett Phinney, Brian F. Byrd, Ripan S. Malhi, and Glendon Parker

2020 A Comparison of Proteomic, Genomic, and Osteological Methods of Archaeological Sex Estimation. Scientific Reports 10(11897):1-15.
Camacho, Morgana, and Karl J. Reinhard

2020 Pinworm Research in the Southwest USA: Five Decades of Methodological and Theoretical Development and the Epidemiological Approach. Archaeological and Anthropological Sciences 12:63. DOI:10.1007/ s12520-019-00994-2.

Ceddia, Michele G., Nicholas O. Bardsley, Robin Goodwin, Garth J. Holloway, Giuseppe Nocella, and Antonio Stasi

2013 A Complex System Perspective on the Emergence and Spread of Infectious Diseases: Integrating Economic and Ecological Aspects. Ecological Economics 90:124-131. DOI:10.1016/j.ecolecon.2013.03.013.

Chavez, Aliyah

2020 Two Pueblos Have Some of the Highest Infection Rates in US. Indian Country Today, 7 April. Electronic document, https://indiancountrytoday.com/news/twopueblos-have-some-of-the-highest-infection-rates-in-us5IAXXwxfsU6gLdWcR74tnA, last accessed August 2, 2020.

Collison, Patrick J.

2013 Bastions, Beads, Baptisms, and Burials: Evidence for Epidemic Disease among the Arikara and Their Ancestors. Plains Anthropologist 58:9-43.

Costa, Diogo M.

2016 Archaeology of the African Slaves in the Amazon. Journal of African Diaspora Archaeology and Heritage 5:198-221

Costa, Maria A., Carney Matheson, Lucia Iachetta, Agustín Llagostera, and Otto Appenzeller

2009 Ancient Leishmaniasis in a Highland Desert of Northern Chile. PLoS ONE 4(9):e6983. DOI:10.1371/ journal.pone.0006983.

Creese, John L.

2017 Beyond Representation: Indigenous Economies of Affect in the Northeast Woodlands. In Foreign Objects: Rethinking Indigenous Consumption in American Archaeology, edited by Craig N. Cipolla, pp. 59-79. University of Arizona Press, Tucson.

Darling, Millie, and Helen D. Donoghue

2014 Insights from Paleomicrobiology into the Indigenous Peoples of Pre-Colonial America: A Review. Memorias Instituto Oswaldo Cruz 109(2):131-139.

Dávalos, Liliana, Rita M. Austin, Mairin A. Balisi, Rene L. Begay, Courtney A. Hofman, Melissa E. Kemp, Justin R. Lund, Cara Monroe, Alexis M. Mychajliw, Elizabeth A. Nelson, Maria A. Nieves-Colón, Sergio A. Redondo, Susanna Sabin, Krystal S. Tsosie, and Joseph M. Yracheta

2020 Pandemics' Historical Role in Creating Inequality. Proceedings of the National Academy of Sciences of the United States of America 117:1322-1323. DOI:10. 1073/pnas.2005584117.

de la Cova, Carlina

2011 Race, Health, and Disease in 19th-Century-Born Males. American Journal of Physical Anthropology 144:526-537. DOI:10.1002/ajpa.21434.

2014 The Biological Effects of Urbanization and In-Migration on 19th-Century-Born African Americans and Euro-Americans of Low Socioeconomic Status. In Modern Environments and Human Health, edited by Molly K. Zuckerman, pp. 243-264. John Wiley \& Sons, Hoboken, New Jersey. DOI:10.1002/ 9781118504338.

Delle, James A.

2019 The Archaeology of Northern Slavery and Freedom. University Press of Florida, Gainesville. 
DeWitte, Sharon N.

2015 Setting the Stage for Medieval Plague: Pre-Black Death Trends in Survival and Mortality: Pre-Black Death Demographic Trends. American Journal of Physical Anthropology 158:441-451. DOI:10.1002/ajpa. 22806.

2016 Archaeological Evidence of Epidemics Can Inform Future Epidemics. Annual Review of Anthropology 45:63-77. DOI:10.1146/annurev-anthro-102215-095929.

DeWitte, Sharon N., and James W. Wood

2008 Selectivity of Black Death Mortality with Respect to Preexisting Health. Proceedings of the National Academy of Sciences of the United States of America 105:1436-1441. DOI:10.1073/pnas.0705460105.

Diamond, Jared

1999 Guns, Germs, and Steel: The Fates of Human Societies. W. W. Norton, New York.

2002 Evolution, Consequences and Future of Plant and Animal Domestication. Nature 418:700-707. DOI:10. 1038/nature01019.

Dickx, Veerle, and Daisy Vanrompay

2011 Zoonotic Transmission of Chlamydia psittaci in a Chicken and Turkey Hatchery. Journal of Medical Microbiology 60:775-779.

Dobyns, Henry F.

1983 Their Number Become Thinned: Native American Population Dynamics in Eastern North America. University of Tennessee Press, Knoxville.

Dunnavant, Justin

2017 Access Denied: African Americans and Access to End-of-Life Care in Nineteenth-Century Washington, DC. Historical Archaeology 51:114-130.

Earle, Rebecca

2012 The Body of the Conquistador: Food, Race and the Colonial Experience in Spanish America, 1492-1700. Cambridge University Press, New York.

Eerkens, Jelmer W., Ruth V. Nichols, Gemma G. R. Murray, Katherine Perez, Engel Murga, Phil Kaijankoski, Jeffrey S. Rosenthal, Laurel Engbring, and Beth Shapiro

2018 A Probable Prehistoric Case of Meningococcal Disease from San Francisco Bay: Next Generation Sequencing of Neisseria meningitidis from Dental Calculus and Osteological Evidence. International Journal of Paleopathology 22:173-180.

Epperson, Terrence W.

2004 Critical Race Theory and the Archaeology of the African Diaspora. Historical Archaeology 38(1):101108.

Farlow, Jason, David M. Wagner, Meghan Dukerich, Miles Stanley, May Chu, Kristy Kubota, Jeannine Petersen, and Paul Keim

2005 Francisella tularensis in the United States. Emerging Infectious Diseases 11:1835-1841.

Farmer, Paul

2004 An Anthropology of Structural Violence. Current Anthropology 45:305-325.

Ferguson, Leland G.

1992 Uncommon Ground: Archaeology and Early African America, 1650-1800. Smithsonian Institution, Washington, DC.

Flannery, Kent V., and Joyce Marcus

2012 The Creation of Inequality: How Our Prehistoric Ancestors Set the Stage for Monarchy, Slavery, and Empire. Harvard University Press, Cambridge, Massachusetts.
Fournié, Guillaume, Dirk U. Pfeiffer, and Robin Bendrey

2017 Early Animal Farming and Zoonotic Disease Dynamics: Modelling Brucellosis Transmission in Neolithic Goat Populations. Royal Society Open Science 4(2). DOI:10.1098/rsos.160943.

Fox, Keolu

2020 The Illusion of Inclusion-The "All of Us" Research Program and Indigenous Peoples' DNA. New England Journal of Medicine 383:411-413.

Fracchia, Adam

2019 Ruins, Resources, and Archaeology: Valuing People and Spaces in Baltimore. Historical Archaeology 53:516-534

Franklin, Maria

1997 "Power to the People": Sociopolitics and the Archaeology of Black Americans. Historical Archaeology 31(3):36-50.

Franklin, Maria, and Nedra K. Lee

2019 Revitalizing Tradition and Instigating Change: Foodways at the Ransom and Sarah Williams Farmstead, c. 1871-1905. Journal of African Diaspora Archaeology and Heritage 8:202-225.

2020 African American Descendants, Community Outreach, and the Ransom and Sarah Williams Farmstead Project. Journal of Community Archaeology and Heritage 7:135-148.

Franklin, Maria, and Samuel Wilson

2020 A Bioarchaeological Study of African American Health and Mortality in the Post-Emancipation U.S. South. American Antiquity 85:652-675.

González-Tennant, Edward

2018 The Rosewood Massacre: An Archaeology and History of Intersectional Violence. University Press of Florida, Gainesville.

Graff, Rebecca S.

2019 An Ardent Anti-Slavery Tale: Narrating Resistance through Chicago's Underground Railroad, 1856Present. Journal of Community Archaeology and Heritage 6:85-97.

Gray, D. Ryan

2020 Race, Public Housing, and the Archaeology of Four Lost New Orleans Neighborhoods. University of Alabama Press, Tuscaloosa.

Hardin, Margaret A., and Barbara J. Mills

2000 The Social and Historical Context of Short-Term Stylistic Replacement: A Zuni Case Study. Journal of Archaeological Method and Theory 7:139-163.

Harper, Kristin N., Molly K. Zuckerman, Megan L. Harper, John D. Kingston, and George J. Armelagos

2011 The Origin and Antiquity of Syphilis Revisited: An Appraisal of Old World Pre-Columbian Evidence for Treponemal Infection. American Journal of Physical Anthropology 146:99-133.

Hendy, Jessica, Matthew Collins, Kai Yik Teoh, David A. Ashford, Jane Thomas-Oates, Helen D. Donoghue, Ildikó Pap, David E. Minnikin, Mark Spigelman, and Mike Buckley.

2016 The Challenge of Identifying Tuberculosis Proteins in Archaeological Tissues. Journal of Archaeological Science 66:146-153.

Hendy, Jessica, Christina Warinner, Abigail Bouwman, Matthew J. Collins, Sarah Fiddyment, Roman Fischer, Richard Hagan, Courtney A. Hofman, Malin Holst, Eros Chaves, Lauren Klaus, Greger Larson, Meaghan Mackie, Krista McGrath, Amy Z. Mundorff, Anita Radini, Huiyun Rao, Christian Trachsel, Irina M. 
Velsko, and Camilla F. Speller

2018 Proteomic Evidence of Dietary Sources in Ancient Dental Calculus. Proceedings of the Royal Society B: Biological Sciences 285. DOI:10.1098/rspb.2018.0977.

Hoggarth, Julie A., Matthew Restall, James W. Wood, and Douglas J. Kennett

2017 Drought and Its Demographic Effects in the Maya Lowlands. Current Anthropology 58:82-113. DOI:10. 1086/690046.

Holland-Lulewicz, Jacob, Victor D. Thompson, James Wettstaed, and Mark Williams

2020 Enduring Traditions and the (Im)materiality of Early Colonial Encounters in the Southeastern United States. American Antiquity 85:694-714.

Hollenback, Kacy LeAnne

2012 Disaster, Technology, and Community: Measuring Responses to Smallpox Epidemics in Historic Hidatsa Villages, North Dakota. PhD dissertation, School of Anthropology, University of Arizona, Tucson.

Hull, Kathleen Louann

2009 Pestilence and Persistence: Yosemite Indian Demography and Culture in Colonial California. University of California Press, Berkeley.

Hutchinson, Dale L.

2016 Disease and Discrimination: Poverty and Pestilence in Colonial Atlantic America. University Press of Florida, Gainesville.

Indian Health Service

2020 Fact Sheets: Disparities. Electronic document, https:// www.ihs.gov/newsroom/factsheets/disparities/, accessed September 13, 2020

Jones, Eric E.

2014 Spatiotemporal Analysis of Old World Diseases in North America, A.D. 1519-1807. American Antiquity 79:487-506.

Jonsson, Colleen B., Luiz Tadeu, Moraes Figueiredo, and Olli Vapalahti

2010 A Global Perspective on Hantavirus Ecology. Clinical Microbiology Reviews 23:412-441.

Kay, Gemma L., Martin J. Sergeant, Zhemin Zhou, Jacqueline Z.-M. Chan, Andrew Millard, Joshua Quick, Ildikó Szikossy, Ildikó Pap, Mark Spigelman, Nicholas J. Loman, Mark Achtman, Helen D. Donoghue, and Mark J. Pallen

2015 Eighteenth-Century Genomes Show That Mixed Infections Were Common at Time of Peak Tuberculosis in Europe. Nature Communications 6:6717. DOI:10. 1038/ncomms 7717 .

Kendall, Ellen J., Janney Montgomery, Jane A. Evans, Christina Stantis, and V. Mueller

2013 Mobility, Mortality, and the Middle Ages: Identification of Migrant Individuals in a 14th Century Black Death Cemetery Population. American Journal of Physical Anthropology 150:210-222. DOI:10.1002/ ajpa.22194.

Kintigh, Keith W., Jeffrey Altschul, Mary Beaudry, Robert Drennan, Ann Kinzig, Timothy Kohler, W. Frederick Limp, Herbert Maschner, William Michener, Timothy Pauketat, Peter Peregrine, Jeremy Sabloff, Tony Wilkinson, Henry Wright, and Melinda Zeder

2014 Grand Challenges for Archaeology. American Antiquity 79:5-24.

Kobasa, Darwyn, Ayato Takada, Kyoko Shinya, Masato Hatta, Peter Halfmann, Steven Theriault, Hiroshi Suzuki, Hidekazu Nishimura, Keiko Mitamura, Norio Sugaya, Taichi Usui, Takeomi Murata, Yasuko
Maeda, Shinji Watanabe, M. Suresh, Takashi Suzuki, Yasuo Suzuki, Heinz Feldmann, and Yoshihiro Kawaoka

2004 Enhanced Virulence of Influenza A Viruses with the Haemagglutinin of the 1918 Pandemic Virus. Nature 431:703-707.

Kohler, Timothy A.

2012 Complex Systems and Archaeology. In Archaeological Theory Today, edited by Ian Hodder, pp. 93 123. Polity Press, Malden, Massachusetts.

Kohler, Timothy A., Michael E. Smith, Amy Bogaard, Gary M. Feinman, Christian E. Peterson, Alleen Betzenhauser, Matthew Pailes, Elizabeth C. Stone, Anna Marie Prentiss, Timothy J. Dennehy, Laura J. Ellyson, Linda M. Nicholas, Ronald K. Falseit, Amy Styring, Jade Whitlam, Mattio Fochesato, Thomas A. Foor, and Samuel Bowles

2017 Greater Post-Neolithic Wealth Disparities in Eurasia Than North America and Mesoamerica. Nature 551:619-622.

Krause, Richard A., and Kacy L. Hollenback

2016 A Brief Context-Dependent Study of Arikara Ceramic Change. Plains Anthropologist 61:394-409.

Kvamme, Kenneth L., and Stanley A. Ahler

2007 Integrated Remote Sensing and Excavation at Double Ditch State Historic Site, North Dakota. American Antiquity 72:539-561.

Lambert, Patricia M.

2006 Infectious Disease among Enslaved African Americans at Eaton's Estate, Warren County, North Carolina, ca. 1830-1850. Memórias do Instituto Oswaldo Cruz 101(Suppl. 2):107-117.

Lambert, Patricia M.

2017 Treponematosis in Indigenous North America: Bioarchaeological Perspectives on the Epidemiological Landscape of a Spirochete Disease. American Journal of Physical Anthropology Supplement 64:255-256.

LaRoche, Cheryl J.

2014 Free Black Communities and the Underground Railroad: The Geography of Resistance. University of Illinois Press, Urbana.

Larsen, Clark S.

1994 In the Wake of Columbus: Native Population Biology in the Postcontact Americas. Yearbook of Physical Anthropology 37:109-154.

Lee, Nedra K.

2019 Boarding: Black Women in Nantucket Generating Income and Building Community. Transforming Anthropology 27:91-104.

Lehmann, Tovi, Paula L. Marcet, Doug H. Graham, Erica R. Dahl, and Jitender P. Dubey

2006 Globalization and the Population Structure of Toxoplasma gondii. Proceedings of the National Academy of Sciences of the United States of America 103:1142311428 .

Lelièvre, Michelle A., and Maureen E. Marshall

2015 "Because Life It Selfe Is but Motion": Toward an Anthropology of Mobility. Anthropological Theory 15:434-471.

Lewis, Carenza

2016 Disaster Recovery: New Archaeological Evidence for the Long-Term Impact of the "Calamitous" Fourteenth Century. Antiquity 351:777-797. DOI:10. 15184/aqy.2016.69.

Liebmann, Matthew J., Joshua Farella, Christopher I. Roos, Adam Stack, Sarah Martini, and Thomas W. Swetnam 
2016 Native American Depopulation, Reforestation, and Fire Regimes in the Southwest United States, 1492 1900 CE. Proceedings of the National Academy of Sciences of the United States of America 113:E696E704.

Lightfoot, Kent G., and Sara L. Gonzalez

2018 The Study of Sustained Colonialism: An Example from the Kashaya Pomo Homeland in Northern California. American Antiquity 83:427-443.

Lipe, William D., R. Kyle Bocinsky, Brian S. Chisholm, Robin Lyle, David M. Dove, R. G. Matson, Elizabeth Jarvis, Kathleen Judd, and Brian M. Kemp

2016 Cultural and Genetic Contexts for Early Turkey Domestication in the Northern Southwest. American Antiquity 81:97-113.

Lloyd-Price, Jason, Galeb Abu-Ali, and Curtis Huttenhower 2016 The Healthy Human Microbiome. Genome Medicine 8:51. DOI:10.1186/s13073-016-0307-y.

Madley, Benjamin

2019 California's First Mass Incarceration System: Franciscan Missions, California Indians, and Penal Servitude, 1769-1836. Pacific Historical Review 88:14-47.

Mann, Charles C.

2005 1491: New Revelations of the Americas before Columbus. Alfred A. Knopf, New York.

Margos, Gabriele, Anne G. Gatewood, David M. Aanensend, Klára Hanincová, Darya Terekhova, Stephanie A. Vollmer, Muriel Cornet, Joseph Piesman, Michael Donaghy, Antra Bormane, Merrilee A. Hurn, Edward J. Feil, Durland Fish, Sherwood Casjens, Gary P. Wormser, Ira Schwartz, and Klaus Kurtenbach

2008 MLST of Housekeeping Genes Captures Geographic Population Structure and Suggests a European Origin of Borrelia burgdorferi. Proceedings of the National Academy of Sciences of the United States of America 105:8730-8735.

Martin, Debra L., and Alan H. Goodman

2002 Health Conditions before Columbus: Paleopathology of Native North Americans. Culture and Medicine 176:65-68.

Matthews, Christopher N., and Allison Manfra McGovern (editors)

2015 Archaeology of Race in the Northeast. University Press of Florida, Gainesville.

McDavid, Carol

1997 Descendants, Decisions, and Power: The Public Interpretation of the Archaeology of the Levi Jordan Plantation. Historical Archaeology 31(3):114-131.

Meier, Mischa

2016 The "Justinianic Plague": The Economic Consequences of the Pandemic in the Eastern Roman Empire and Its Cultural and Religious Effects. Early Medieval Europe 24:267-292.

Mendieta, Gerónimo de, OFM

1971 Historia Eclesiástica Indiana, Vol. 4. Editorial Porrua, Mexico.

Merbs, Charles

1992 A New World of Infectious Disease. Yearbook of Physical Anthropology 35:3-42.

Hegmon Michelle, and Matthew A. Peeples, on behalf of the LTVTP-NABO collaboration

2018 The Human Experience of Social Transformation: Insights from Comparative Archaeology. PLOS ONE 13(11):e0208060. DOI:10.1371/journal.pone.0208060.

Mordechai, Lee, Merle Eisenberg, Timothy P. Newfield, Adam Izdebski, Janet E. Kay, and Hendrik Poinar
2019 The Justinianic Plague: An Inconsequential Pandemic? Proceedings of the National Academy of Sciences of the United States of America 116:2554625554.

Balanzátegui Moreno, Daniela Catalina

2018 Collaborative Archaeology to Revitalize an AfroEcuadorian Cemetery. Journal of African Diaspora Archaeology and Heritage 7:42-69.

Mühlemann, Barbara, Lasse Vinner, Ashot Margaryan, Helene Wilhelmson, Constanza de la Fuente Castro, Morten E. Allentoft, Peter de Barros Damgaard, Anders Johannes Hansen, Sofie Holtsmark Nielsen, Lisa Mariann Strand, Jan Bill, Alexandra Buzhilova, Tamara Pushkina, Ceri Falys, Valeri Khartanovich, Vyacheslav Moiseyev, Marie Louise Schjellerup Jørkov, Palle Østergaard Sørensen, Yvonne Magnusson, Ingrid Gustin, Hannes Schroeder, Gerd Sutter, Geoffrey L. Smith, Christian Drosten, Ron A. M. Fouchier, Derek J. Smith, Eske Willerslev, Terry C. Jones, and Martin Sikora

2020 Diverse Variola Virus (Smallpox) Strains Were Widespread in Northern Europe in the Viking Age. Science 369:eaaw8977. DOI:10.1126/science.aaw8977.

National Library of Medicine

2020 Timeline: 2009: H1N1 Flu Mortality Four Times Higher among American Indians. Electronic document, https://www.nlm.nih.gov/nativevoices/timeline/653.html, accessed September 13, 2020.

Nerlich, Andreas G.

2018 Molecular Paleopathology and Paleo-OncologyState of the Art, Potentials, Limitations and Perspectives. International Journal of Paleopathology 21:77-82.

Nerlich, Andreas G., Helmut Rohrbach, Beatrice Bachmeier, and Albert Zink

2006 Malignant Tumours in Two Ancient Populations: An Approach to Historical Tumour Epidemiology. Oncology Reports 16:197-202.

New Mexico Department of Health

2020 Coronavirus Disease 2019 in New Mexico. Electronic document, https://cv.nmhealth.org/, accessed September 13, 2020.

New York Times

2019 The 1619 Project. Electronic document, https:// www.nytimes.com/interactive/2019/08/14/magazine/ 1619-america-slavery.html, accessed September 23, 2020.

Nickell, Zachary D., and Matthew D. Moran

2017 Disease Introduction by Aboriginal Humans in North America and the Pleistocene Extinction. Journal of Ecological Anthropology 19:29-40.

Odewale, Alicia, and Karla Slocum

2020 \#TulsaSyllabus. Electronic document, https://tulsa syllabus.web.unc.edu/, accessed June 30, 2020.

Orser, Charles E., Jr.

1990 Archaeological Approaches to New World Plantation Slavery. Archaeological Method and Theory 2:111-154.

1994 The Archaeology of African-American Slave Religion in the Antebellum South. Cambridge Archaeological Journal 4:33-45.

Ortner, Donald J., and Walter G. J. Putschar

1981 Identification of Pathological Conditions in Human Skeletal Remains. Smithsonian Institution, Washington, DC.

Pääbo, Svante, Hendrick Poinar, David Serre, Viviane Jaenicke-Després, Juliane Hebler, Nadin Rohland, 
Melanie Kuch, Johannes Krause, Linda Vigilant, and Michael Hofreiter

2004 Genetic Analyses from Ancient DNA. Annual Review of Genetics 38:645-679.

Patz, Jonathan A., Diarmid Campbell-Lendrum, Tracey Holloway, and Jonathan A. Foley

2005 Impact of Regional Climate Change on Human Health. Nature 438:310-317. DOI:10.1038/nature04188.

Paynter, Robert, and Whitney Battle-Baptiste

2019 Contexts of Resistance in African American Western Massachusetts: A View from the W. E. B. Du Bois Homesite in Great Barrington, Massachusetts. Historical Archaeology 53:323-340.

Pepperell, Caitlin S., Julie M. Granka, David C. Alexander, Marcel A. Behr, Linda Chui, Janet Gordon, Jennifer L. Guthrie, Francis B. Jamieson, Deanne Langlois-Klassen, Richard Long, Dao Nguyen, Wendy Wobeser, and Marcus W. Feldman

2011 Dispersal of Mycobacterium Tuberculosis via the Canadian Fur Trade. Proceedings of the National Academy of Sciences of the United States of America 108:6526-6531.

Powell, Mary L., and Della C. Cook (editors)

2005 The Myth of Syphilis: The Natural History of Treponematosis in North America. University Press of Florida, Gainesville.

Prem, Hanns

1992 Disease Outbreaks in Central Mexico during the Sixteenth Century. In Secret Judgments of God: Old World Disease in Colonial Spanish America, edited by Noble David Cook and W. George Lovell, pp. 20-48. University of Oklahoma Press, Norman.

Preston, William L.

2002 Portents of Plague from California's Protohistoric Period. Ethnohistory 49:69-121.

Ramenofsky, Ann

2003 Native American Disease History: Past, Present and Future Directions. World Archaeology 35:241-257. DOI: $10.1080 / 0043824032000111407$.

Rasmussen, Simon, Morten Erik Allentoft, Kasper Nielsen, Ludovic Orlando, Martin Sikora, Karl-Göran Sjögren, Anders Gorm Pedersen, Mikkel Schubert, Alex Van Dam, Christian Moliin Outzen Kapel, Henrik Bjørn Nielsen, Søren Brunak, Pavel Avetisyan, Andrey Epimakhov, Mikhail Viktorovich Khalyapin, Artak Gnuni, Aivar Kriiska, Irena Lasak, Mait Metspalu, Vyacheslav Moiseyev, Andrei Gromov, Dalia Pokutta, Lehti Saag, Liivi Varul, Levon Yepiskoposyan, Thomas SicheritzPontén, Robert A. Foley, Marta Mirazón Lahr, Rasmus Nielsen, Kristian Kristiansen, and Eske Willerslev

2015 Early Divergent Strains of Yersinia pestis in Eurasia 5,000 Years Ago. Cell 163:571-582. DOI:10.1016/j. cell.2015.10.009.

Reid, Ann H., Thomas G. Fanning, Johan V. Hultin, and Jeffery $\mathrm{K}$. Taubenberger

1999 Origin and Evolution of the 1918 "Spanish" Influenza Virus Hemagglutinin Gene. Proceedings of the National Academy of Sciences of the United States of America 96:1651-1656.

Riede, Felix

2017 Past-Forwarding Ancient Calamities. Pathways for Making Archaeology Relevant in Disaster Risk Reduction Research. Humanities 6(4):79. DOI:10.3390/ h6040079.

Roberts, Charlotte A., and Jane E. Buikstra

2003 The Bioarchaeology of Tuberculosis: A Global View on a Reemerging Disease. University Press of Florida, Gainesville.

Rohr, Jason R., Christopher B. Barrett, David J. Civitello, Meggan E. Craft, Bryan Delius, Giulio A. DeLeo, Peter J. Hudson, Nicolas Jouanard, Karena H. Nguyen, Richard S. Ostfeld, Justin V. Remais, Gilles Riveau, Susanne H. Sokolow, and David Tilman

2019 Emerging Human Infectious Diseases and the Links to Global Food Production. Nature Sustainability 2(6):445-456. DOI:10.1038/s41893-019-0293-3.

Roman, Sonia, Alexis Jose-Abrego, Nora Alma Fierro, Griselda Escobedo-Melendez, Claudia Ojeda-Granados, Erika Martinez-Lopez, and Arturo Panduro

2014 Hepatitis B Virus Infection in Latin America: A Genomic Medicine Approach. World Journal of Gastroenterology 20:7181-7196.

Rosenzweig, Melissa S.

2020 Confronting the Present: Archaeology in 2019. American Anthropologist 122:284-305.

Salo, Wilmar L., Arthur C. Aufderheide, Jane Buikstra, and Todd A. Holcomb

1994 Identification of Mycobacterium tuberculosis DNA in a Pre-Columbian Peruvian Mummy. Proceedings of the National Academy of Sciences of the United States of America 91:2091-2094.

Samford, Patricia M.

2007 Subfloor Pits and the Archaeology of Slavery in Colonial Virginia. University of Alabama Press, Tuscaloosa.

Sawicki, Vincent A., Marvin J. Allison, Harry P. Dalton, and Alejandro Pezzia

1976 Presence of Salmonella Antigens in Feces from a Peruvian Mummy. Bulletin of the New York Academy of Medicine 52:805-813.

Schaul, Kevin, Brittany Renee Mayes, and Bonnie Berkowitz 2020 Where Americans Are Still Staying at Home the Most. Washington Post, May 6. Electronic document, https://www.washingtonpost.com/graphics/2020/national/ map-us-still-staying-home-coronavirus/?itid=hp_visualstories-8-12_no-name:homepage/story-ans, accessed May $18,2020$.

Schneider, Tsim D.

2015 Envisioning Colonial Landscapes Using Mission Registers, Radiocarbon, and Stable Isotopes: An Experimental Approach from San Francisco Bay. American Antiquity 80:511-529.

Schuenemann, Verena J., Aditya Kumar Lankapalli, Rodrigo Barquera, Elizabeth A. Nelson, Diana Iraíz Hernández, Víctor Acuña Alonzo, Kirsten I. Bos, Lourdes Márquez Morfín, Alexander Herbig, and Johannes Krause

2018 Historic Treponema pallidum Genomes from Colonial Mexico Retrieved from Archaeological Remains. PLoS Neglected Tropical Diseases 12(6):e0006447. DOI:10.1371/journal.pntd.0006447.

Scott, Eugene

2020 The Audacity of Those Comparing "Open Up" Protesters to Rosa Parks. Washington Post. 1 May. Electronic document, https://www.washingtonpost.com/politics/ 2020/05/01/problems-with-holding-up-open-up-protesterslegacy-rosa-parks/, accessed May 18, 2020.

Singleton, Theresa (editor)

1985 The Archaeology of Slavery and Plantation Life. Academic Press, Orlando, Florida.

Singleton, Theresa

1995 The Archaeology of Slavery in North America. Annual Reviews in Anthropology 24:119-140. 
2010 Archaeology and Slavery. In The Oxford Handbook on Slavery in the Americas, edited by Mark M. Smith and Robert L. Paquette, pp. 702-724. Oxford University Press, Oxford. DOI:10.1093/oxfordhb/9780199227990. 013.0033.

Skoglund, Pontus, Jan Storå, Anders Götherström, and Mattias Jakobsson

2013 Accurate Sex Identification of Ancient Human Remains Using DNA Shotgun Sequencing. Journal of Archaeological Science 40:4477-4482. DOI:10.1016/ j.jas.2013.07.004.

Smith, Oliver, and M. Thomas P. Gilbert

2019 Ancient RNA. In Paleogenomics: Genome-Scale Analysis of Ancient DNA, edited by Charlotte Lindqvist and Om P. Rajora, pp. 53-74. Springer, Cham, Switzerland.

Smith, Bruce D., and Melinda A. Zeder

2013 The Onset of the Anthropocene. Anthropocene 4:8 13. DOI:10.1016/j.ancene.2013.05.001.

Speir, Matthew L., Ann S. Zweig, Kate R. Rosenbloom, Brian J. Raney, Benedict Paten, Parisa Nejad, Brian T. Lee, Katrina Learned, Donna Karolchik, Angie S. Hinrichs, Steve Heitner, Rachel A. Harte, Maximilian Haeussler, Luvina Guruvadoo, Pauline A. Fujita, Christopher Eisenhart, Mark Diekhans, Hiram Clawson, Jonathan Casper, Galt P. Barber, David Haussler, Robert M. Kuhn, and W. James Kent

2016 The UCSC Genome Browser Database: 2016 Update. Nucleic Acids Research 44(D1):D717-D725. DOI:10.1093/nar/gkv1275.

Trigger, Bruce $\mathrm{G}$.

2006 History of Archaeological Thought. 2nd ed Cambridge University Press, Cambridge.

Wallace, Birgitte

2003 The Norse in Newfoundland: L'Anse aux Meadows and Vinland. Newfoundland and Labrador Studies 19:5-43.

Warinner, Christina, Jessica Hendy, Camilla Speller, Enrico Cappellini, Roman Fischer, Christian Trachsel, Jette Arneborg, N. Lynnerup, Oliver E. Craig, D. M. Swallow, A. Fotakis, R. J. Christensen, J. V. Olsen, A. Liebert, N. Montalva, S. Fiddyment, S. Charlton, M. Mackie, A. Canci, A. Bouwman, F. Rühli, M. T. P. Gilbert, and M. Collins

2014 Direct Evidence of Milk Consumption from Ancient Human Dental Calculus. Scientific Reports 4:7104.

Warinner, Christina, João F. Matias Rodrigues, Rounak Vyas, Christian Trachsel, Natallia Shved, Jonas Grossmann, Anita Radini, Y. Hancock, Raul Y. Tito, Sarah Fiddyment, Camilla Speller, Jessica Hendy, Sophy Charlton, Hans Ulrich Luder, Domingo C. SalazarGarcía, Elisabeth Eppler, Roger Seiler, Lars H. Hansen, José Alfredo Samaniego Castruita, Simon Barkow-Oesterreicher, Kai Yik Teoh, Christian D. Kelstrup, Jesper V. Olsen, Paolo Nanni, Toshihisa Kawai, Eske Willerslev, Christian von Mering, Cecil M. Lewis Jr., Matthew J. Collins, M. Thomas P. Gilbert, Frank Rühli, and Enrico Cappellini

2014 Pathogens and Host Immunity in the Ancient Human Oral Cavity. Nature Genetics 46:336-344.
Warinner, Christina, Camilla Speller, Matthew J. Collins, and Cecil M. Lewis Jr.

2015 Ancient Human Microbiomes. Journal of Human Evolution 79:125-136. DOI:10.1016/j.jhevol.2014.10. 016.

Watkins, Rachel

2012 Variation in Health and Socioeconomic Status within the W. Montague Cobb Skeletal Collection: Degenerative Joint Disease, Trauma and Cause of Death. International Journal of Osteoarchaeology 22:22-44. DOI:10.1002/oa.1178.

Weik, Terrance

2004 Archaeology of the African Diaspora in Latin America. Historical Archaeology 38(1):32-49.

Wertheim, Joel O., Martin D. Smith, Davey M. Smith, Kondrad Scheffler, and Sergei L. Kosakovsky Pond

2014 Evolutionary Origins of Human Herpes simplex Viruses 1 and 2. Molecular and Biological Evolution 31:2356-2364

Wiessner, Polly

1983 Style and Social Information in Kalahari San Projectile Points. American Antiquity 48:253-276.

Wilkie, Laurie

2019 At Freedom's Borderland: The Black Regulars and Masculinity at Fort Davis, Texas. Historical Archaeology 53:126-137.

Willerslev, Eske, and Alan Cooper

2005 Ancient DNA. Proceedings of the Royal Society B: Biological Sciences 272:3-16.

Wobst, Martin

1977 Stylistic Behavior and Information Exchange. In Papers for the Director: Research Essays in Honor of James B. Griffin, edited by Charles E. Cleland, pp. 317-342. Anthropology Papers 61. Museum of Anthropology, University of Michigan, Ann Arbor.

Wolfe, Nathan D., Claire P. Dunavan, and Jared Diamond

2007 Origins of Major Human Infectious Diseases. Nature 447:279-283.

Wolfe, Nathan D., Ananias A. Escalante, William B. Karesh, Annelisa Kilbourn, Andrew Spielman, and Altaf A. Lal

1998 Wild Primate Populations in Emerging Infectious Disease Research: The Missing Link? Emerging Infectious Diseases 4:149-158.

Wood, James W., George R. Milner, Henry C. Harpending, Kenneth M. Weiss, Mark N. Cohen, Leslie E. Eisenberg, Dale L. Hutchinson, Rimantas Jankauskas, Gintautas Cesnys, Gintautas Cesnys, M. Anne Katzenberg, John R. Lukacs, Janet W. McGrath, Eric Abella Roth, Douglas H. Ubelaker, and Richard G. Wilkinson

1992 The Osteological Paradox: Problems of Inferring Prehistoric Health from Skeletal Samples. Current Anthropology 33:343-370.

Zeder, Melinda

1991 Feeding Cities: Specialized Animal Economy in the Ancient Near East. Smithsonian Institution, Washington DC.

Submitted August 3, 2020; Revised September 14, 2020; Accepted September 17, 2020 